\title{
38. NEOGENE VOLCANIC ASHES AND EXPLOSIVE VOLCANISM: JAPAN TRENCH TRANSECT, LEG 57, DEEP SEA DRILLING PROJECT
}

\author{
Jean-Paul Cadet, Département des Sciences de la Terre, Université d'Orléans, 45046 Orléans, France \\ and \\ Kantaro Fujioka, Ocean Research Institute, University of Tokyo, Nakano, Tokyo, Japan
}

\begin{abstract}
The study of the main characteristics of ash layers in Leg 57 cores shows that they are suitable for an analysis of the effect on eruptive activity of their distribution. We found (1) sediment recovery good and ash layers numerous; (2) sedimentary environment generally free from terrigenous clastic material; (3) reworking limited; (4) volcanic glass very acidic, ranging from rhyolitic to rhyodacitic composition; and (5) alteration and diagenesis negligible above the lower Miocene.

The curves of explosive volcanic activity in Holes 438, 439, and 440 display two stages of high activity: an early one around $16 \mathrm{~m} . \mathrm{y}$. and a late one starting $5 \mathrm{~m} . \mathrm{y}$. B.P., both stages being separated by an upper Miocene quiescence. Detail in these results is limited by the chemical composition of the glass and accounts only for trends in explosive acid volcanism. Nevertheless, results are roughly in agreement with other data from the Northwest Pacific, although some discrepancies in the correlation of intensity of the episodes occur. The data from Leg 57 support the hypothesis of synchronous pulses in explosive volcanism.
\end{abstract}

\section{INTRODUCTION}

During Deep Sea Drilling Project Leg 57, Glomar Challenger drilled four sites in the continental shelf (on the broad deep sea terrace, $1500 \mathrm{~m}$ deep, sampled at Sites 438 and 439) and on the trench inner slope (Sites 440 and 441) off northern Honshu Island in order to complete a transect of the Japan Trench begun during Leg 56.

We expected to recover an adequate record of the explosive volcanism of the Japanese island arc, as the examination of continuously cored deep sea sediments has proved to be one of the best means of determining the eruptive history of these arcs. Indeed, Leg 57 sites (Figure 1) are favorably situated for obtaining a complete record of the explosive volcanicity of these areas because of the proximity of the nearby Japan arc (Sites 438 and 439 are approximately $130 \mathrm{~km}$ from Honshu), their position under the prevailing westerlies, and their location on the outer fore-arc, which is fixed, relative to the eruptive centers on the Japanese islands (location on a moving oceanic plate modifies the explosive volcanism record: cf. Ninkovich and Donn, 1976).

\section{ASH AT LEG 57 SITES}

\section{Site $\mathbf{4 3 8}$}

This site is located on the deep sea terrace, $40 \mathrm{~km}$ landward from the top of the Japan trench. The holes, which begin at a water depth of 1500 meters, penetrate nearly flat-lying, locally fractured or faulted, diato-

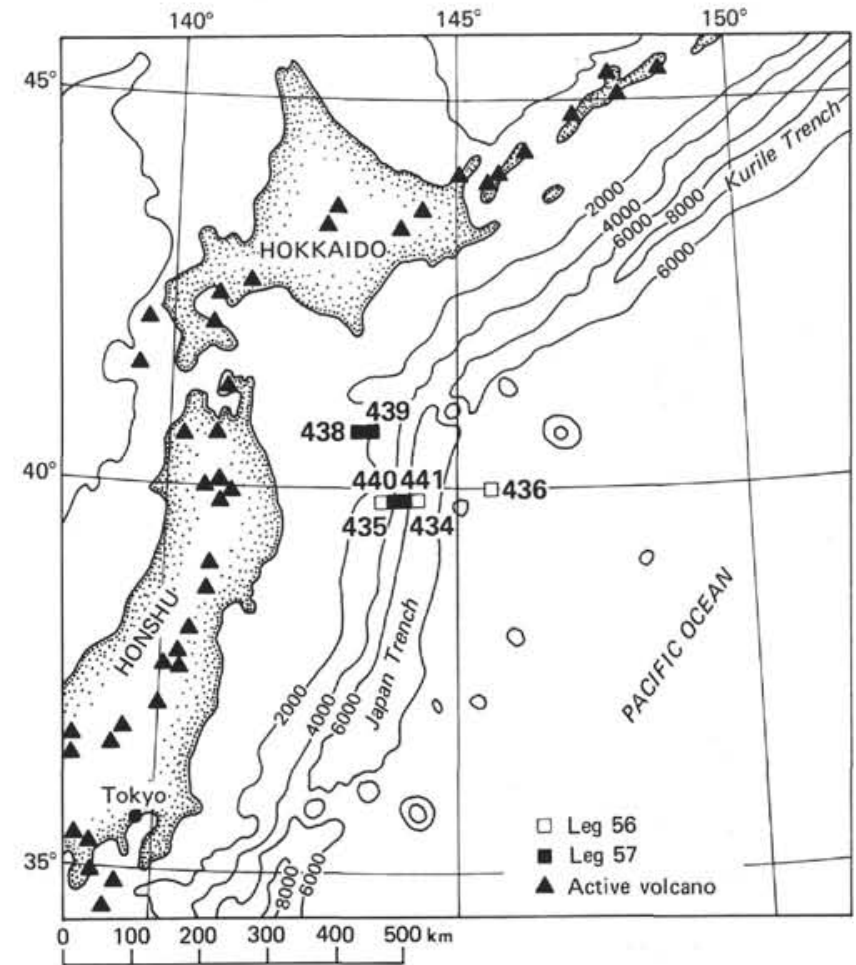

Figure 1. Location of sites drilled on the Japan Trench transect (DSDP Legs 56 and 57).

maceous strata ranging in age from lower Miocene to Holocene. 
Pumice fragments, ash layers, and disseminated volcanic glass occur in most intervals, and continuous coring and good recovery allow a reliable estimate of the timing of volcanic activity of the arc.

Volcanic glass occurs both as grains disseminated within sediment and concentrated in distinct layers. Disseminated volcanic glass shards are abundant in the PlioPleistocene sediments of Holes 438 and 438A (5-15 per cent of the sediment) and in the middle and lower Miocene of Holes 438A and 438B (up to 20 per cent) with generally small amounts ( $2-5$ per cent) through the remainder of the section (Figures 1 and 2).

Ash layers are variable in character and very numerous (more than 100 in Hole 438B). Color is usually white, light gray, and bluish gray to darker shades of gray. Average thickness of ash horizons is 2 to $3 \mathrm{~cm}$ but reaches a maximum thickness of $10 \mathrm{~cm}$ (e.g., in Section 438-10-6). The ash layers consist of silt-sized to coarse sand-sized glass shards (65-95 per cent) which are angular, clear, and colorless; they also contain minor amounts of feldspars, quartz, hornblende, very rare biotite, augite-hypersthene, and pyrite.

\section{Site 439}

This site was drilled just $5 \mathrm{~km}$ east of Site 438 at a water depth of less than 1656 meters. Core recovery is poor in middle Miocene strata but some tuff layers, light gray to grayish black, silt-sized, sometimes graded, ranging from 0.3 to $3 \mathrm{~cm}$, commonly occur in lower Miocene cores.

\section{Site 440}

Site 440 was drilled on the midslope terrace of the landward slope of the Japan trench at a water depth of 4515 meters. Core recovery was sufficiently good so that a nearly continuous record of numerous ash layers can be observed. Although very similar to those at Site 438, they are rarely more than $1 \mathrm{~cm}$ thick, with a maximum of $5 \mathrm{~cm}$ (Sample 440-5-3, 80-90 cm), light gray to dark gray, mainly silty, sometimes graded.

\section{Site 441}

This site is located downslope from Site 440 , at a water depth of 5656 meters. Core recovery was poormainly chips or cuttings-so no firm conclusions can be drawn from the record at this site (Figure 3).

\section{CONDITIONS AND PROBLEMS OF THE EXPLOSIVE VOLCANISM RECORD AT LEG 57 SITES}

We shall first describe the sedimentary environment, modes of sedimentation, chemical composition, and diagenesis of the ash layers. Next we analyze the patterns of eruptive activity which derive from their distribution.

\section{Sedimentary Environment}

The sedimentary sequence, from the early Miocene and later, is generally free from terrigenous clastic material and composed mostly of hemipelagic sediments.

At Sites 438 and 439 it consists of diatomaceous sandy-silty clay of the late Pliocene through Holocene,

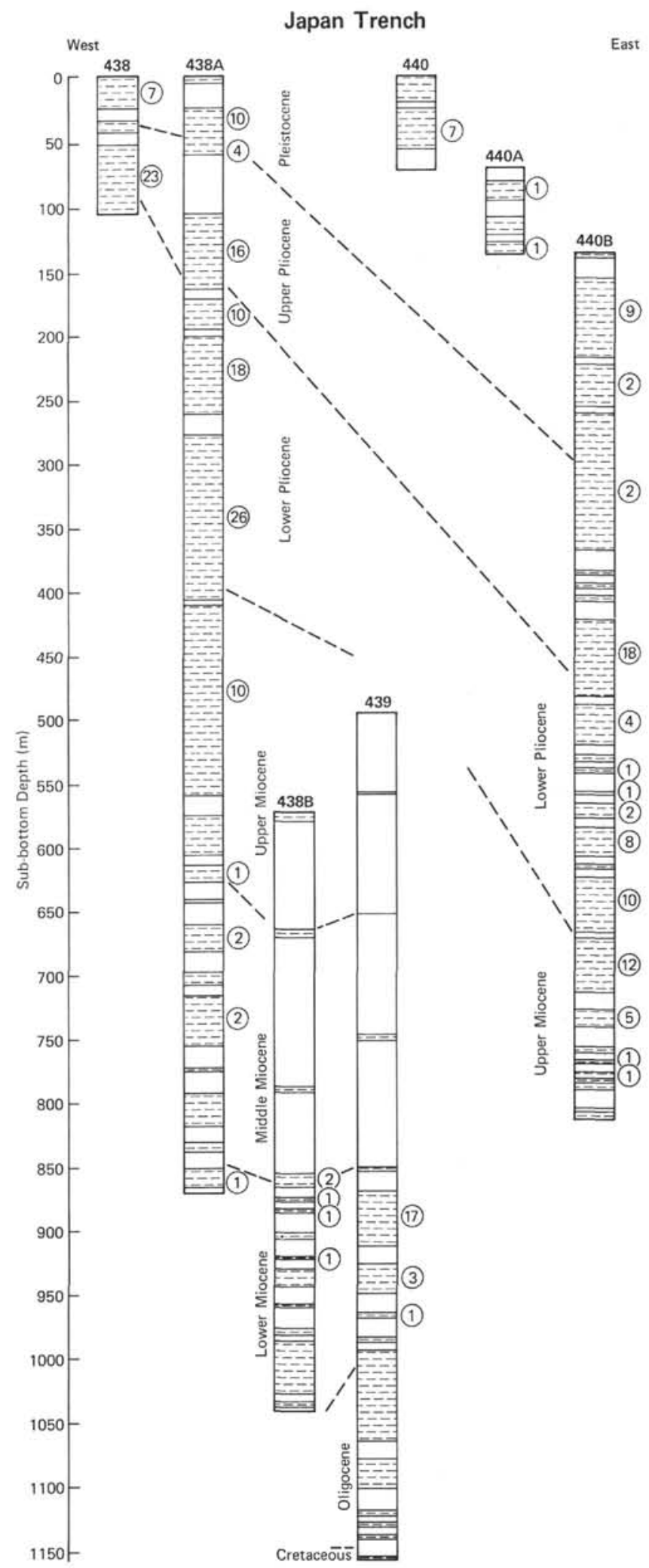

Figure 2. Columns showing the recovery in the nearly continuous cored sections for DSDP Sites 438, 439 (deep sea terrace), and 440 (midslope terrace) in the Japan area. (Circled numbers are the number of ash layers in the recovered sediments sections.) 


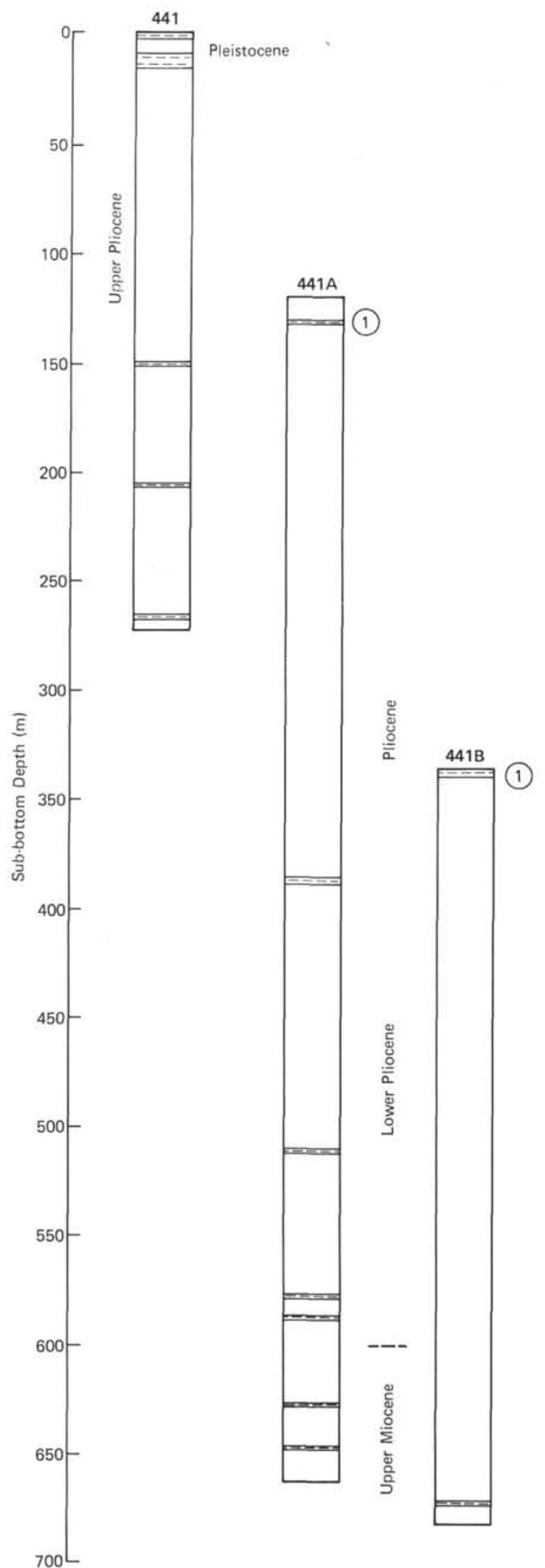

Figure 3. Columns showing the small core recovery for DSDP Site 441 (inner trench slope). thick diatomaceous ooze and clay or claystone of Miocene age, then of distal turbidites of the early Miocene overlying massive sandstones and siltstones and bouldder-to-pebble conglomerate of Oligocene age.

At Site 440, clayey sands and diatomaceous silty and sandy clay and ooze (Holocene-upper Pliocene) and diatomaceous clays and claystones (upper MiocenePliocene) were recovered.

There are ash layers at all levels except in the Oligocene sandstone and conglomerate. Although intense volcanism on Honshu is known from near the Oligocene/Miocene boundary (Sugimura and Uyeda, 1973), the absence of evidence of volcanism at Site 439 is probably due to conditions of deposition in a high-energy environment and/or a rapid sedimentation rate to which the effect of diagenetic processes are added.

\section{Sedimentation and Redeposition}

Some ash layers (about 20 per cent) are composed almost entirely of volcanic glass (more than 85 per cent) and contain as a detrital part only subordinate quartz and clay. In these cases, deposition can be related primarily to transport through the atmosphere by the westerlies from the nearby Japan arc and fall through the water column (cf. Shaw et al., 1974). Generally, these ashes are fine grained (silt- and clay-sized), and if grading occurs, it may be the result of normal settling rate differences between particles of different size in their fall through the water column; this assumption is reinforced by the well-sorted, highly angular character of the glass and the fine size of particles, both of which suggest dispersal by air rather than rafting.

However, most of the ash beds (about 55 per cent of ash layers contain between 65 and 85 per cent volcanic glass) are intimately mixed with terrigenous material and other components such as quartz (an average 12 per cent in Hole 438, 7 per cent in 438A, 8 per cent in 439, and about 6 per cent in 440B), diatoms ( 3 per cent in all holes), and clay (11 per cent in $438 \mathrm{~A}, 14$ per cent in 439 , and 12 per cent in 440B). These beds are often graded and were probably redeposited by either turbidity or other bottom currents. Nevertheless, when reworking is not too great, it can be assumed that individual ash layers or group of ash layers, especially when they are interbedded with clays or claystones, can be related to a single phase of volcanic activity in the Japan arc system to the west of the sites.

\section{Chemical Composition}

Petrographic and chemical studies of Leg 57 ash layers were carried out mainly by Fujioka et al. (this volume), and the following information below is essentially from their study.

Ash layers, as regards volcanic constituents, are composed mainly of glass but also commonly of plagioclase (ranging from $\mathrm{An}_{73}$ to $\mathrm{An}_{7}$ ), hornblende, hypersthene, augite, rare biotite, and magnetite, with many variations.

Volcanic glasses are mostly silt-sized and vary from $2.5 \mathrm{~mm}$ to $0.04 \mathrm{~mm}$ (coarse sand to silt-sized) with a clear, almost transparent aspect. Their refractive index 
ranges from 1.496 to 1.529 , corresponding to that of rhyolitic to rhyodacitic composition. Scarce basaltic glass were also noted.

Chemical analyses of volcanic glass were carried out by Fujioka et al. (this volume) with a complement of about 70 (selected and listed in Table 1) by Cadet performed with an electron probe microanalyzer (Camebax) after a simple sample preparation (following the methods of Smith and Westgate, 1969).

The results of these analyses can be summarized as follows:

1) $\mathrm{SiO}_{2}$ content is always very high (64-80 per cent, with an average of 70 per cent), ranging from rhyodacitic to rhyolitic composition.

2) $\mathrm{Al}_{2} \mathrm{O}_{3}$ varies from about 10 to 15 per cent, with 11 per cent commonest. The volcanic rocks with the same $\mathrm{SiO}_{2}$ content show a similar percentage of $\mathrm{Al}_{2} \mathrm{O}_{3}$.

3) $\mathrm{FeO}$ and $\mathrm{MgO}$ content is approximately 2 per cent, although it can be as low as 0.5 per cent. The $\mathrm{FeO} / \mathrm{MgO}$ ratio is variable but very high, which denotes the highly differentiated character of these rocks.

These findings are characteristic of rhyolitic and rhyodacitic glass, and the chemical composition suggests that all the volcanic glass falls into the nonalkalic rock series (the trend is both calc-alkalic and tholeitic) in the $\mathrm{SiO}_{2}-\left(\mathrm{Na}_{2} \mathrm{O}+\mathrm{K}_{2} \mathrm{O}\right)$ diagram (Kuno, 1966) and shows trends similar to the tholeitic rock series in the $\mathrm{FeO}-\left(\mathrm{Na}_{2} \mathrm{O}+\mathrm{K}_{2} \mathrm{O}\right)-\mathrm{MgO}$ diagram.

Ash layers sampled during Leg 57 contain only rhyolitic and rhyodacitic components and thus provide information only about acidic explosive volcanism.

\section{Alteration and Diagenesis}

Recently the study of Hein and Scholl (1978) on Aleutian arc Cenozoic volcanism has shown the necessity of taking into account diagenesis, which reduces the number of ash layers, while considering altered ash beds as a record of explosive volcanic activity. For example, ash beds that have been transformed in smectitic clay minerals (montmorillonite and/or nontronite) and zeolites (such as clinoptilolite or phillipsite) are subsequently very difficult to recognize by visual inspection. Their detection requires detailed analysis by $\mathrm{X}$-ray diffraction with extensive samplings; thus in this chapter we give only an indication of the degree of alteration.

Alteration observed from the smear slides always seems very weak, and glass is fresh even in lower Miocene sediment-probably because of the high silica content and the relatively low geothermal gradient (see $\mathrm{Ar}$ thur and von Huene, this volume) at the sites. Preliminary scanning electron microscopy (SEM) studies of the glass after ultrasonic cleaning show distinctive etching patterns on grains without clay coating.

Systematic examination reveals a kind of dissolution sequence (Plates 2 and 3 ) from essentially fresh glass (Pleistocene) to the most severely attacked grains (lower Miocene), very similar to the processes illustrated by Berner and Holdren (1977) for the dissolution, during weathering, of feldspar by selective etching of the surface. On the other hand, Iijima and Matsumoto (this volume) note that no zeolites occur in the post-lower Miocene sediments in Hole 438A, but clinoptilolite is

TABLE 1

Microprobe Analysis of 15 Representative Ash Layers, Pleistocene to Lower Miocene

\begin{tabular}{|c|c|c|c|c|c|c|c|c|c|c|c|}
\hline \multirow{2}{*}{$\begin{array}{c}\text { Sample } \\
\text { (Top of interval } \\
\text { in } \mathrm{cm} \text { ) }\end{array}$} & \multirow[b]{2}{*}{ Age } & \multicolumn{10}{|c|}{ Composition (\%) } \\
\hline & & $\mathrm{SiO}_{2}$ & $\mathrm{TiO}_{2}$ & $\mathrm{Al}_{2} \mathrm{O}_{3}$ & $\mathrm{FeO}$ & $\mathrm{MnO}$ & $\mathrm{MgO}$ & $\mathrm{CaO}$ & $\mathrm{Na}_{2} \mathrm{O}$ & $\mathrm{K}_{2} \mathrm{O}$ & Total \\
\hline \multicolumn{12}{|l|}{ Hole 438A } \\
\hline $2-5,20$ & Pleistocene & 75.92 & 0.17 & 12.51 & 1.29 & 0.00 & 0.25 & 1.36 & 1.98 & 2.99 & 96.47 \\
\hline $6-2,72$ & upper Pliocene & 74.79 & 0.13 & 12.18 & 1.32 & 0.00 & 0.09 & 1.21 & 2.44 & 3.15 & 95.31 \\
\hline $11-4,38$ & upper Pliocene & 73.68 & 0.04 & 11.84 & 1.42 & 0.67 & 0.13 & 1.36 & 3.17 & 1.90 & 94.21 \\
\hline $14-4,43$ & lower Pliocene & 73.43 & 0.29 & 11.33 & 2.16 & 0.02 & 0.33 & 1.78 & 2.57 & 1.82 & 93.73 \\
\hline $24-1,98$ & lower Pliocene & 72.88 & 0.11 & 11.99 & 0.74 & 0.09 & 0.09 & 1.02 & 4.58 & 2.09 & 93.59 \\
\hline $32-3,90$ & lower Pliocene & 73.93 & 0.17 & 12.18 & 0.91 & 0.08 & 0.21 & 1.99 & 2.91 & 1.96 & 94.34 \\
\hline $33-4,73$ & lower Pliocene & 74.79 & 0.13 & 12.15 & 0.87 & 0.07 & 0.16 & 1.02 & 2.16 & 3.31 & 94.66 \\
\hline $43-6,11$ & upper Miocene & 73.21 & 0.00 & 12.12 & 0.52 & 0.09 & 0.03 & 0.39 & 2.13 & 4.37 & 92.86 \\
\hline $59-3,67$ & upper Miocene & 71.97 & 0.08 & 12.12 & 1.88 & 0.08 & 0.14 & 1.46 & 2.39 & 2.57 & 92.69 \\
\hline \multicolumn{12}{|l|}{ Hole 438B } \\
\hline $4-1,77$ & middle Miocene & 74.77 & 0.17 & 11.69 & 0.77 & 0.04 & 0.04 & 0.87 & 2.83 & 3.86 & 95.04 \\
\hline \multicolumn{12}{|l|}{ Hole 439} \\
\hline $8-2,124$ & lower Miocene & 69.03 & 0.43 & 14.50 & 2.25 & 0.01 & 0.45 & 3.17 & 2.36 & 2.13 & 94.33 \\
\hline $11-3,71$ & lower Miocene & 71.85 & 0.27 & 12.14 & 1.68 & 0.06 & 0.22 & 1.31 & 2.63 & 2.76 & 92.92 \\
\hline \multicolumn{12}{|l|}{ Hole 440} \\
\hline $4-6,134$ & Pleistocene & 73.49 & 0.03 & 13.11 & 0.56 & 0.13 & 0.04 & 2.25 & 3.01 & 3.26 & 95.88 \\
\hline \multicolumn{12}{|l|}{ Hole 440B } \\
\hline $3-1,32$ & Pleistocene & 75.85 & 0.17 & 11.82 & 1.19 & 0.03 & 0.16 & 1.32 & 1.86 & 1.81 & 94.21 \\
\hline $34-2,27$ & upper Pliocene & 74.43 & 0.17 & 12.17 & 1.01 & 0.12 & 0.20 & 1.02 & 2.37 & 1.64 & 93.13 \\
\hline
\end{tabular}

Note: BRGM-CNRS Camebax electron probe microanalyzer. 
detected in lower Miocene tuffaceous and siliceous sandy mudstones of Hole 439 (in Core 14, Section 3, Core 16 , Section 3), replacing silicic glass shards associated with montmorillonite and low cristobalite (first stage of alteration of glass shards, Murata and Whiteley, 1973). Thus from 0 to approximately 935 meters, the sedimentary column is characterized by the presence of fresh to slightly altered silica glass and an absence of zeolites. Mann and Muller (this volume) also indicate that nonaltered glass exists down to 930 meters in Site 439, and altered glass occurs below that level associated with clinoptilolite.

These data emphasize the fact that volcanic glass alteration is probably minor above 930 meters (lower Miocene); that is to say, diagenesis does not interfere with the record of explosive volcanism.

\section{DISTRIBUTION OF ASH LAYERS AND EXPLOSIVE VOLCANISM RECORD}

\section{Methods}

There are many studies that deal with the methods for interpreting the frequency of volcanic activity, based on an examination of the occurrence of ash in DSDP cores. Choice of method depends on what is taken into account and why. Some investigators (Ninkovich and Donn, 1976) count only ash that appears in layers, however discrete; others (Hein, Scholl, and Miller, 1978) consider ash beds and pods but also dispersed ash (if they form more than 15 per cent of the deposit) and bentonite beds (i.e., completely alterated ash beds, Hein and Scholl, 1978). Donnelly (1975) makes a separate evaluation of accumulation rates of total volcanic material and of plagioclase crystals, using estimated total sedimentation rates for the sediment. In the present chapter we take into account all the ash layers, even the most discrete, as well as pods when, after checking when possible with the smear slides that the glass content is above 60 per cent and that the amount of reworked material is low, it can reasonably be assumed that they are related to a single ash layer. This eliminates layers containing reworked pyroclastic material which have thus no strong meaning for a record of volcanicity. For the same reason we do not take into account dispersed volcanic glasses, because their distribution depends mainly on depositional environment (e.g., currents and bioturbation) and does not necessarily imply that the debris deposited is directly related to magma production (but see Arthur and von Huene, this volume, for a presentation and discussion of these data).

Methods for analyzing and displaying the data also vary. Investigators generally plot the number of observed ash layers versus time (Ninkovich and Donn, 1976) or fossil zones (Kennett and Thunell, 1975), and so on. Our procedure is similar to that used by Hein, Scholl, and Miller (1978) for Leg 19: we have divided the sediment section into intervals of $1 \times 10^{6}$ years, using both sedimentation accumulation curves (Figures 4 , 5 , and 6) and diatom fossil zones boundaries defined by Barron (this volume), then counted the number of ash

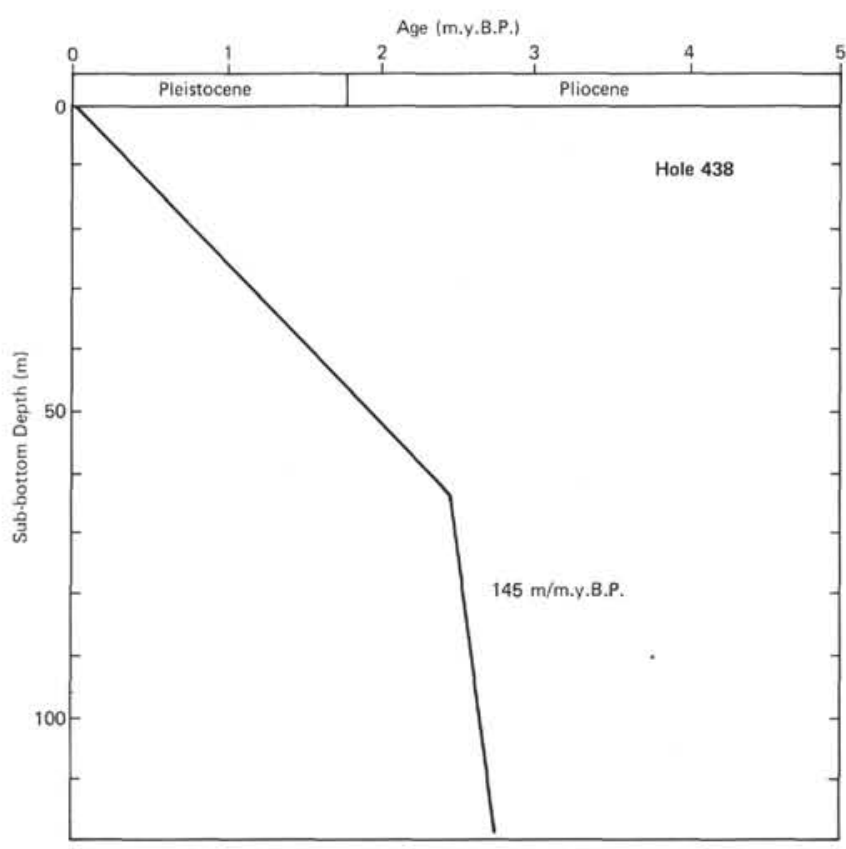

Figure 4. Age-depth curve for DSDP Site 438 showing sediment accumulation rates used for construction of Figure 7.

layers in this interval and adjusted for the degree of core recovery.

\section{Pattern of Explosive Volcanic Activity}

The curves (Figure 7) traced from data from Holes $438,438 \mathrm{~A}, 439,440,440 \mathrm{~A}$, and $440 \mathrm{~B}$ show that volcanic activity rises moderately to a peak between 17 and 16 m.y. B.P. at the lower/middle Miocene boundary, then decreases after a sporadic period of activity near 13 to 12 m.y. B.P. (upper Miocene). From about 8 m.y. B.P., the activity increases again sharply, reaching a maximum between 4 and $3 \mathrm{~m}$.y., during the lower Pliocene. After a decreasing period toward 1.5 m.y. B.P., volcanic activity resumes in the late Pleistocene time. In short, this curve points out two stages of high volcanic activity, an early one around 16 m.y. B.P. and a late one of intense activity starting 5 m.y. B.P., both stages separated by an upper Miocene quiescence.

\section{Correlation from Site to Site}

An analysis of Figure 7 shows good correlation between the data for Sites 438 and 440; that is, their curves, which correspond to periods when the number of ash layers per million years are similar, are parallel. This is particularly true for the Pleistocene and upper Pliocene, between 1 and 2.5 m.y.B.P. (Cores 438-4438-7; 438A-3-438A-5; 440B-7-440B-28) and less so between 5 and 6.5 m.y. B.P.

On the other hand, the data show an apparent difference in the rhythm of explosive volcanism between 3 and $4 \mathrm{~m} . \mathrm{y}$. B.P. which can probably be explained by the distance of Site 440 from the sources of volcanic material in comparison with that of Site 438 , which is more than $50 \mathrm{~km}$. Indeed, the comparison between the cumu- 


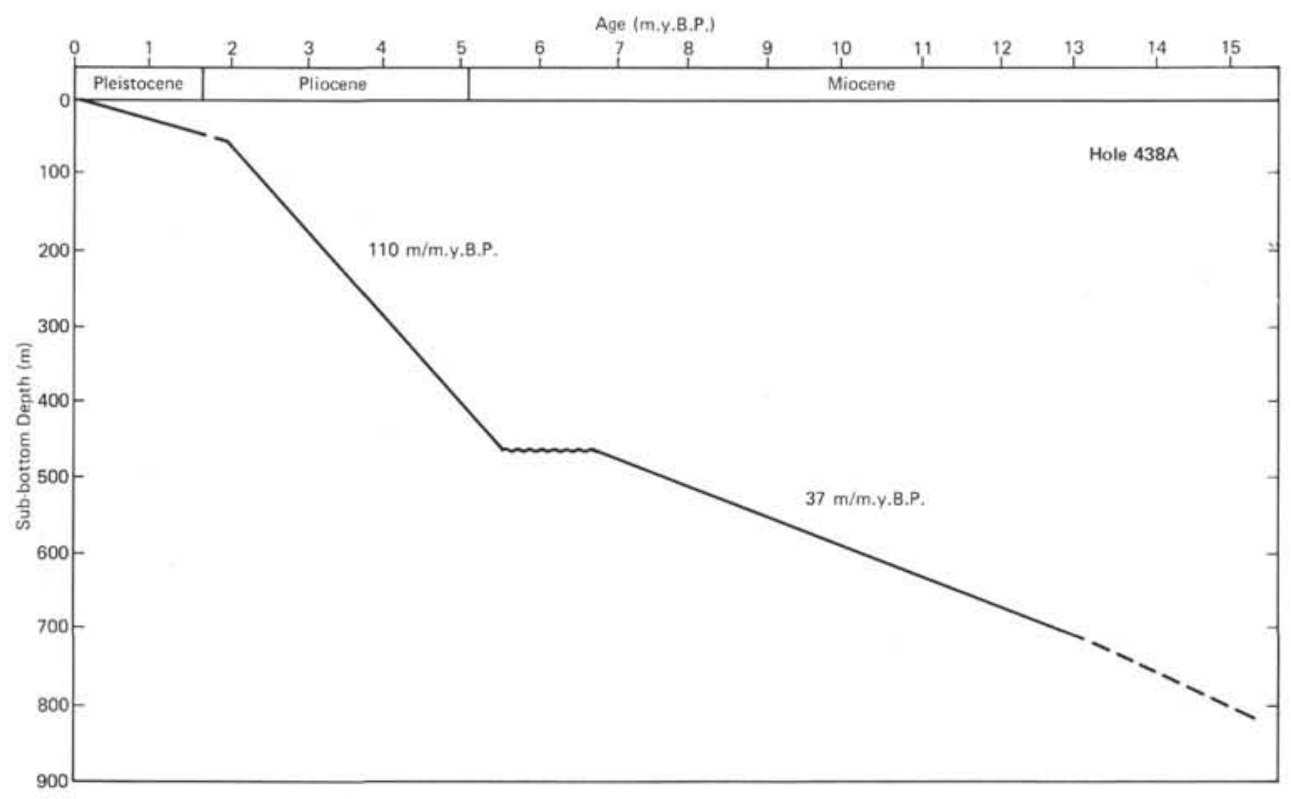

Figure 5. Age-depth curve for Hole $438 \mathrm{~A}$.

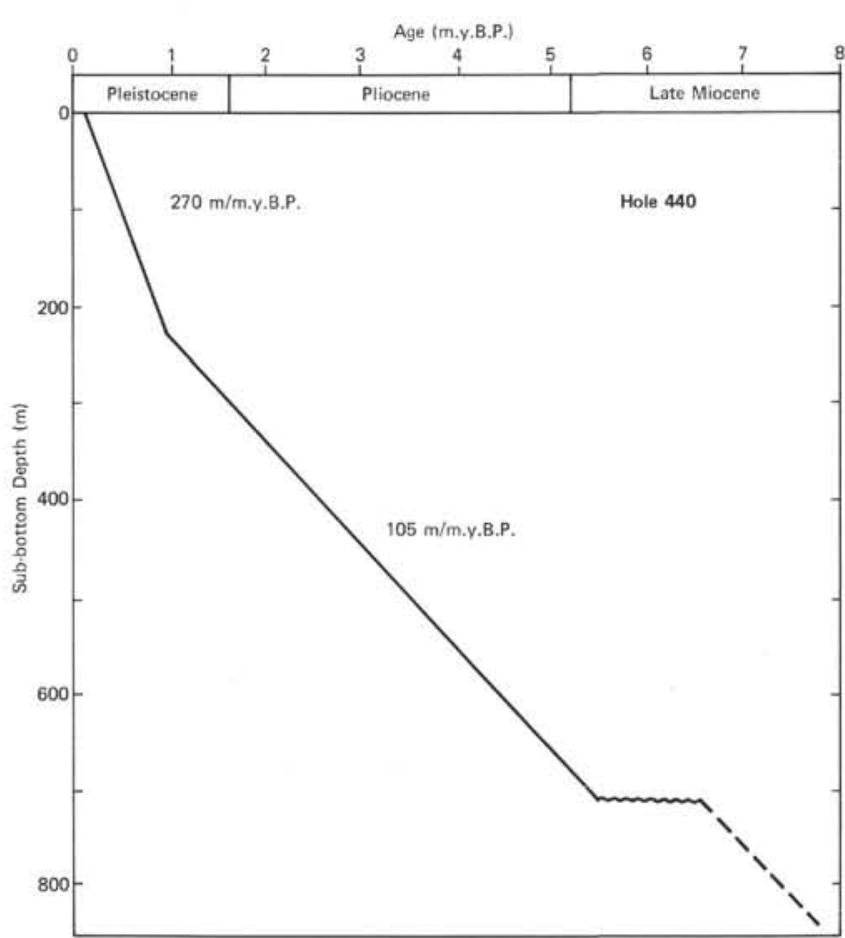

Figure 6. Age-depth curve for Hole 440.

lative thickness of ash layers in the time sequences when they are equally numerous (Holes 438 and 440 ) shows a noticeable thinning eastward. This is the case for the sequence 2.5 to 3 m.y. B.P. in Holes 438 (Cores 5-9) and 440B (Core 29-37), with a very similar number of ash layers (33 in Hole 438A and 30 in 440B, after adjustment for the recovery) where thinning runs to 2.5 eastward.

Between 3 and $4 \mathrm{~m} . y$. B.P., the ash layers are already very thin (about $1 \mathrm{~cm}$ ) in Hole 438A, and it is likely that they do not appear farther east in Hole 440.
Layer to layer correlation, using reflective index variation (e.g., Hays and Ninkovich, 1970; Ninkovich and Robertson, 1975; Keller et al., 1978), is not easy to exercise here because of the high glass homogeneity. However, Fujioka et al. (this volume), using chemical composition, correlate layers in Sections 438-11-5, $30-31 \mathrm{~cm}$, and 438A-6-4, $22-23 \mathrm{~cm}$, and using biostratigraphic data and sedimentation rates correlate Sections $438-7-2,48-50 \mathrm{~cm}$ and $438-7-2,103-105 \mathrm{~cm}$ with those of $438 \mathrm{~A}-5-3,77-85 \mathrm{~cm}$ and the ashy pods below.

\section{DISCUSSION}

A satisfactory recovery rate and a good paleontological control, mainly in the Pleistocene and Pliocene, insure the precision of the curve, but from 16 m.y. B.P. down, sedimentation rates are less precise and the curve only an approximation.

As we emphasized earlier, sedimentary environment, conditions of ash layers deposition, and limited reworking guarantee the quality of the explosive volcanism record; thus we can assume that the number of ash layers has not been reduced by diagenesis.

Our conclusions are limited, however, by the chemical composition. Chemical analyses of glass have shown that acidic components only reached the Japan Trench sites, and the frequency curve shows only that area of Japan volcanic arc activity which has been summarized by Sugimura et al., 1963; Kuno, 1966; and Tanaka and Nozawa, 1977. This volcanism is composed of both acidic and basic products. The difference in the distribution is linked to the higher explosive intensity of acidic magma and to the pattern of ash wind dispersal.

Nevertheless the present analysis of explosive volcanism off Honshu roughly confirms Leg 31 data on the volcanic history of southern Japan through ash layers (Donnelly, 1975), in particular the decline of early Neogene volcanic activity to a minimum value in the upper Mio- 


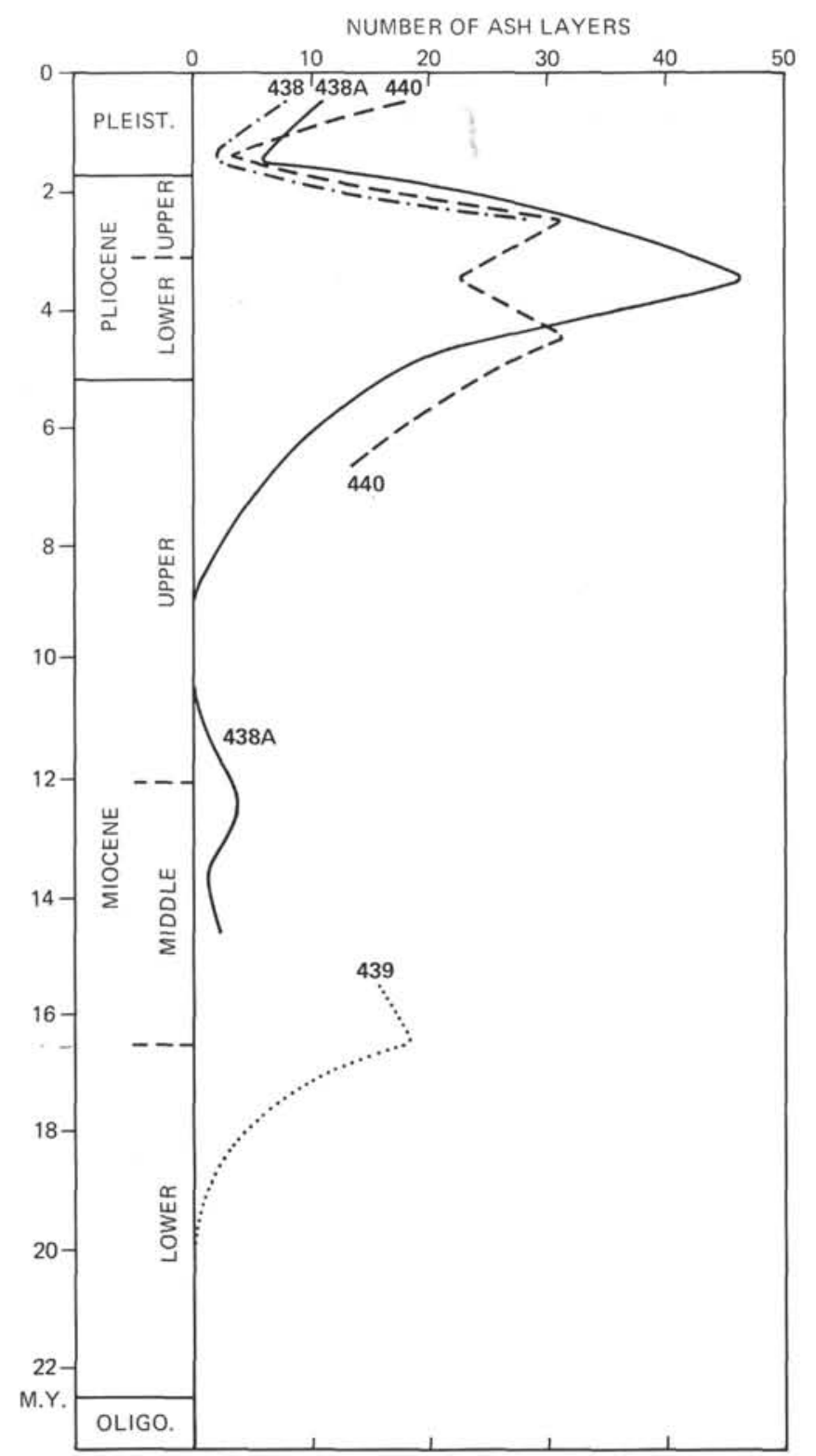

Figure 7. Periods of explosive volcanism in the Japan Trench area as recorded by ash beds (data are plotted at a uniform $1.0 \times 10^{6}$ year interval and with correction for core recovery).

cene (about 11-9 m.y. B.P.) and the sharp increase at the Miocene/Pliocene boundary, which reaches a peak in the lower Pliocene. In the later period there is a succession of less active sequences followed by a more active one.

Our results are also in agreement with Kennett and Thunell's data (1975). Those authors obtained an ash layer distribution graph for the Northwest Pacific using all the DSDP cores recovered in this area. We find roughly the same pulses of volcanic activity but with important discrepancies in the intensity estimate, mainly for the Quaternary, where Kennett and Thunell's curve shows an increase of explosive volcanism three times as important as Leg 57 data do. This difference probably results partially from their consideration of mobile sites situated on the Pacific Plate, as Ninkovich and Donn (1976) pointed out. Study of the Site 436 volcanism record (Furuta and Arai, this volume), which shows that the number of ash layers gradually increases upward as the site moves toward the volcanic sources, confirms the influence of plate motion. Thus it seems that there was a major episode of explosive volcanism during the Quaternary, but our data do not indicate a higher intensity than for the Pliocene and early Miocene.

By compiling the number of radiometric data reported for terrestrial and marine records in the circum-Pacific, Kennett, McBirney, and Thunell (1977) have shown within certain limitations a global correlation in the episodicity of volcanism. Without offering a discussion of their methods and analysis, we can state that three out of four of the important pulses of Neogene volcanism in the circum-Pacific (Quaternary, 2 m.y.B.P.-present; latest Miocene-lower Pliocene, 6-3 m.y.B.P.; and within the middle Miocene, 16-14 m.y.B.P.) occurred with varying intensity according to Leg 57 data, supporting the idea of a link with global variations in subduction zones. The volcanic pulse detected by Kennett et al. in the upper Miocene (11-8 m.y.B.P.), however, does not appear in Hole 438A data.

On land, in the Japan area, the Neogene period (cf. Minato et al., 1965; Sugimura et al., 1963) starts with a period of intense volcanic activity and with the emission of an abundant material composed primarily of lavas and a relatively small amount of tephra (Ninkovich and Robertson, 1975) known as the "Green Tuff" formation. After minor pulses and remissions, the activity has become more intense from the top of the Miocene to the Quaternary in different parts of Japan. Sugimura and Uyeda (1973) emphasized the fact that the most important pulses of volcanism in Japan took place during the early Miocene and the Quaternary. The analysis of ash layer distribution at Leg 57 sites confirms these two major groupings but indicates however, (cf. Donnelly, 1975), that the last period began at the Miocene/Pliocene boundary. On the other hand, the intensity of each period is inverted between land and marine data. Following global estimates by Sugimura and al. (1963) in volume per unit of time, it appears that the early Neogene volcanism was the most violent $\left(25,000 \mathrm{~km}^{3}\right.$ per m.y. for the Quaternary). More recently Horikoshi (1976) indicates that the amount of volcanic rock deposited between 27 m.y.B.P. and 13 m.y.B.P. was much greater than after 13 m.y.B.P. The difference between these data and our results can be explained by the lack of precision of volcanic activity recording for the period from 16 to 20 m.y.B.P. at Site 439 , by the absence of recording earlier than $20 \mathrm{~m}$.y.B.P., and by the fact that the marine record of volcanic activity in Leg 56 sites shows only explosive acid volcanism.

\section{CONCLUSIONS}

The parallelism in data concerning the tempo of explosive volcanism off Honshu and in the neighboring district (Leg 31) confirms that the analysis of ash layer distribution in deep sea cores is one of the best means to 
know the volcanic history in the source areas. However, it also underlines the necessity of carefully discussing the different elements that influence the recording particularly the nature of the material considered, which severely limits intensity evaluation.

Ash layer distribution off Honshu substantiates the hypothesis of synchronous pulses in explosive volcanism and suggests two kind of links, one with the Neogene history of Japan, the other with plate motion in the subduction zone. The Neogene history of Japan (Matsuda, Nakamura, and Sugimura, 1967; Honza, Kagami, and Nasu, 1977) shows that the arc, after a period of emergence at the Oligocene/lower Miocene boundary, subsides during the middle and upper Miocene. After the Miocene/Pliocene boundary, the sea gradually retreated, and the arc was uplited to the present level. The distributuion of volcanism off Honshu suggests that the sequences of high volcanic activity correspond to periods of low sea level, whereas periods of volcanic quiescence coincide with periods of submergence, supporting, as pointed out by Matsuda et al. (1967), the idea of some interrelation between tectonogenesis and volcanism in island arc evolution.

The probable relation as concerns mechanisms between the change of rate of explosive volcanism and plate motion in the subduction zone, if commonly accepted, is not evident. There are many plausible explanations: change in the sinking rate of the ocean lithosphere (Sugimura and Uyeda, 1973; Kennett and Thunell, 1975), the influence of the nature of the subducted crust (cf. Ninkovich et al., 1977), and/or change in the mode of subduction and partitioning of energy between various tectonic manifestations (Helwig and Hal, 1974). The increase in knowledge about Northwest Pacific subduction zones touched on by Legs ( 56 to 60 ), particularly with regard to historical and structural evolution during the Neogene, should enhance, correspondingly, our understanding of the relationship between tectonic regimes, subduction, and explosive volcanism.

\section{ACKNOWLEDGMENTS}

The authors would like to express sincere thanks to their colleagues on the Glomar Challenger and to H. Chamley and $\mathrm{X}$. Le Pichon for their valuable suggestions and critical review of this manuscript. Thanks are also due R. Blanchet and $\mathrm{N}$. Nasu, who contributed much to this paper.

This research was supported by a C.N.R.S. grant (A.T.P. IPOD) to J.-P. Cadet, who is especially grateful to D. Ninkovich and W. B. F. Ryan for their help.

\section{REFERENCES}

Berner, R. A., and Holdren, G. R., 1977. Mechanism of feldspar weathering: Some observational evidence. Geology, 5, 369-372.

Donnelly, T. W., 1975. Neogene explosive volcanic activity of the Western Pacific: Sites 292 and 296, DSDP Leg 31. In Karig, D. E., Ingle, J. C., et al., Init. Repts. DSDP, 31: Washington (U.S. Govt. Printing Office), 577-597.
Hays, J. D., and Ninkovich, D., 1970. North Pacific deep-sea chronology and age of the present Aleutian underthrusting. Geol. Soc. Am. Bull. Mem., 216, 263-290.

Hein, J. R., and Scholl, D. W., 1978. Diagenesis and distribution of late Cenozoic volcanic sediment in the southern Bering Sea. Geol. Soc. Am. Bull., 89, 197-210.

Hein, J. R., Scholl, D. W., and Miller, J., 1978. Episodes of Aleutian Ridge explosive volcanism. Science, 199, 137-141.

Helwig, J., and Hall, G. A., 1974. Steady states trenches. Geology, 2, 309-316.

Honza, E., Kagami, H., and Nasu, N., 1977. Neogene geological history of the Tohoku Island Arc system. J. Oceanog. Soc., 33, 297-310.

Horikoshi, E., 1976. Development of late Cenozoic petrogenic provinces and metallogeny in northeast Japan. Geol. Assoc. Can. Spec. Pap., 14, 121-142.

Keller, J., Ryan, W. B. F., Ninkovich, D., and Altherr, R., 1978. Explosive volcanic activity in the Mediterranean over the past 200,000 years as recorded in deep sea sediments. Geol. Soc. Am. Bull., 89, 591-604.

Kennett, J. P., McBirney, A. R., and Thunell, R. C., 1977. Episodes of Cenozoic volcanism in the circum-Pacific region. J. Volcanol. Geotherm. Res., 2, 145-163.

Kennett, J. P., and Thunell, R. C., 1975. Global increase in Quaternary explosive volcanism. Science, 187, 497-503.

Kuno, H., 1966. Lateral variation of basaltic magma type across continental margins and island arcs. Bull. Volcanol. Ser. 2, 29, 195-222.

Matsuda, T., Nakamura, K., and Sugimura A. 1967. Late Cenozoic orogeny in Japan. Tectonophysics, 4 (4-6), 349-366.

Minato, M., Gorai, M., and Hunahashi, M. (Eds.), 1965. The Geologic Development of the Japanese Islands: Tokyo (Tsukiji-Shokan).

Murata, K. J., and Whiteley, K. R., 1973. Zeolites in the Miocene briones sandstones and related formations of the central coast ranges, California. U. S. Geol. Surv. J. Res., 1, 255-265.

Ninkovich, D., Cadet, J. P., Burckle, L., and Hammond, S., 1977. Le volcanisme explosif de l'arc des Aléoutiennes: Répartition spatio-temporelle des cendres dans les sédiments marins; implications géodynamiques. C. R. Somm. Soc. Géol. Fr., 5, 273-276.

Ninkovich, D., and Donn, W. L., 1976. Explosive Cenozoic volcanism and climatic implications. Science, 194, 899-906.

Ninkovich, D., and Robertson, J. H., 1975. Volcanogenic effects on the rates of deposition of sediments in the northwest Pacific Ocean. Earth Planet. Sci. Lett., 27, 127-136.

Shaw, D. M., Watkins, N. D., and Huang, T. D., 1974. Atmospherically transported volcanic glass in deep sea sediments: Theoretical considerations. J. Geophys. Res., 79, 3087-3094.

Smith, D. G. W., and Westgate, J. A., 1969. Electron probe technique for characterizing pyroclastic deposits. Earth Planet. Sci. Lett., 5, 313-319.

Sugimura, A., Matsuda, T., Chinzei, K., and Nakamura, K., 1963. Quantitative distribution of late Cenozoic volcanic material in Japan. Extrait. Bull. Vocanologique, 26, 125140, Napoli.

Sugimura, A., and Uyeda, S., 1973. Island Arcs: Japan and Its Environs: New York (Elsevier).

Tanaka, K., and Nozawa, T., 1977. Geology and Mineral Resources of Japan (Vol. 1): Kawasaki-shi (Geological Survey of Japan). 


\section{PLATE 1}

Figure 1 Sample 440A-7-4, 12-27 cm, Pleistocene. Typical graded ash layer interbedded in diatomaceous clay. At base is a medium dark gray sandy-silty volcanic ash (volcanic glass 66 per cent, quartz 13 per cent, feldspath 5 per cent, hornblend 6 per cent, clay 5 per cent) grading up into finer silty-clayey light gray ash (volcanic glass 77 per cent, quartz 6 per cent, feldspath 2 per cent, hornblend 1 per cent, clay 12 per cent). The sedimentary environment and composition of the ash layer allow us to think that grading may be mainly the result of different sizes in their fall through the water column.

Figure 2 Sample 439-9-3, 88-110 cm, lower Miocene. Tuff interbedded in burrowed claystone. $89-93 \mathrm{~cm}$ : bluish gray tuff finely graded; $93-96 \mathrm{~cm}$ : parallel black dewatering veins; 102-107 cm: light bluish gray tuff graded from silt to clay, finely laminated and burrowed at top. 
PLATE 1
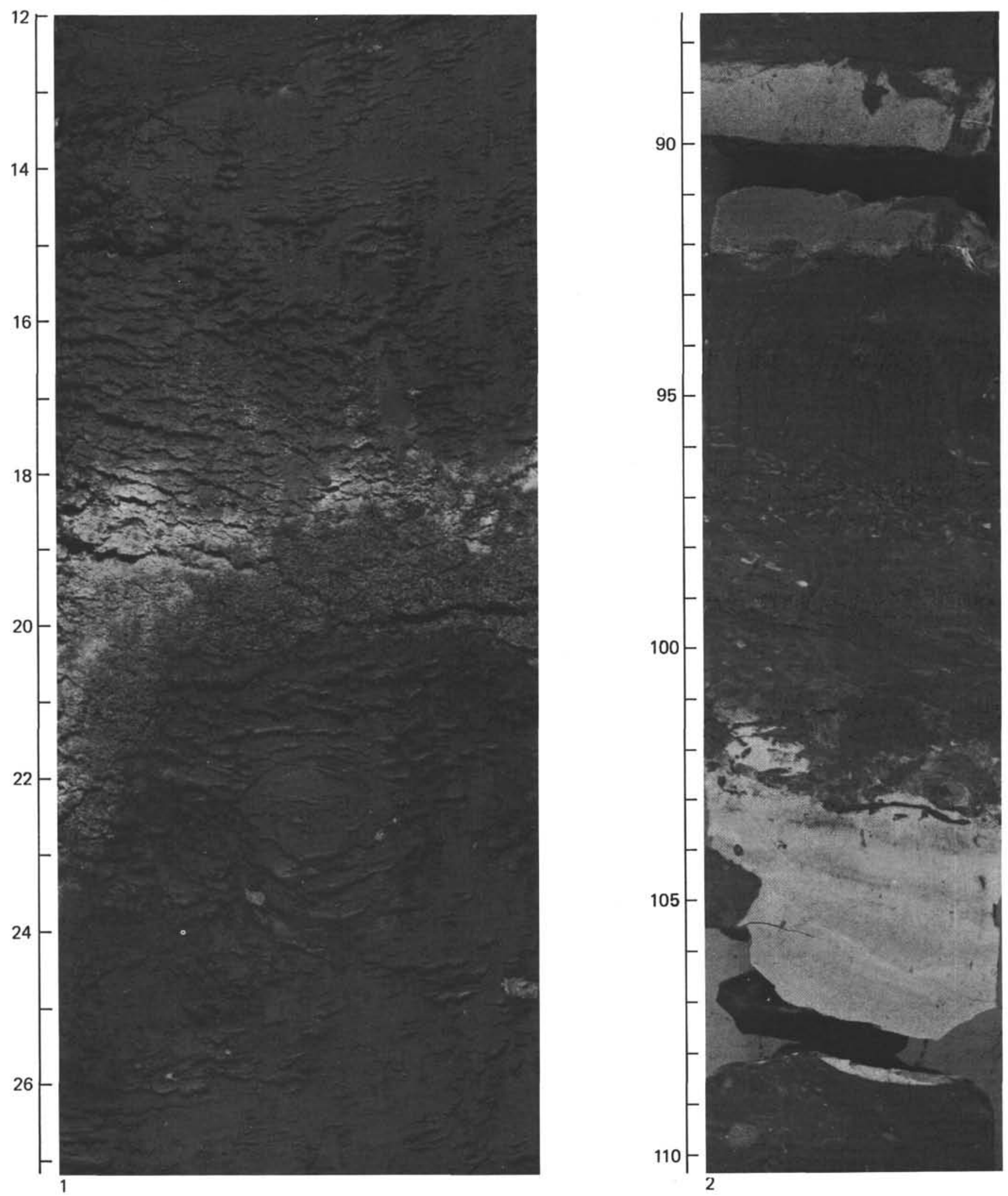
PLATE 2

Typical Glass Morphology

(scanning electron microscope photographs)

Figure 1 Pumice fragment $(\times 400)$, Pleistocene, Sample 438A-2-5, $20 \mathrm{~cm}$.

Figure 2 Bubble glass $(\times 500)$, upper Pliocene, Sample 438A-11-4, $38 \mathrm{~cm}$.

Figure 3 Glass fragment with tubular vesicles $(\times 600)$, upper Pliocene, Sample 438A-11-4, $38 \mathrm{~cm}$.

Figure 4 Vesicular glass $(\times 120)$, lower Pliocene, Sample 438A-32-3, $90 \mathrm{~cm}$.

Figure 5 Elongated glass shard $(\times 300)$, Pleistocene, Sample 438A-2-5, $20 \mathrm{~cm}$.

Figure 6 Detail with high magnification $(\times 2000)$ of Figure 5. The glass surface of this Pleistocene sample is relatively smooth $\left(\mathrm{SiO}_{2}\right.$ content about 76 per cent). 


\section{PLATE 2}
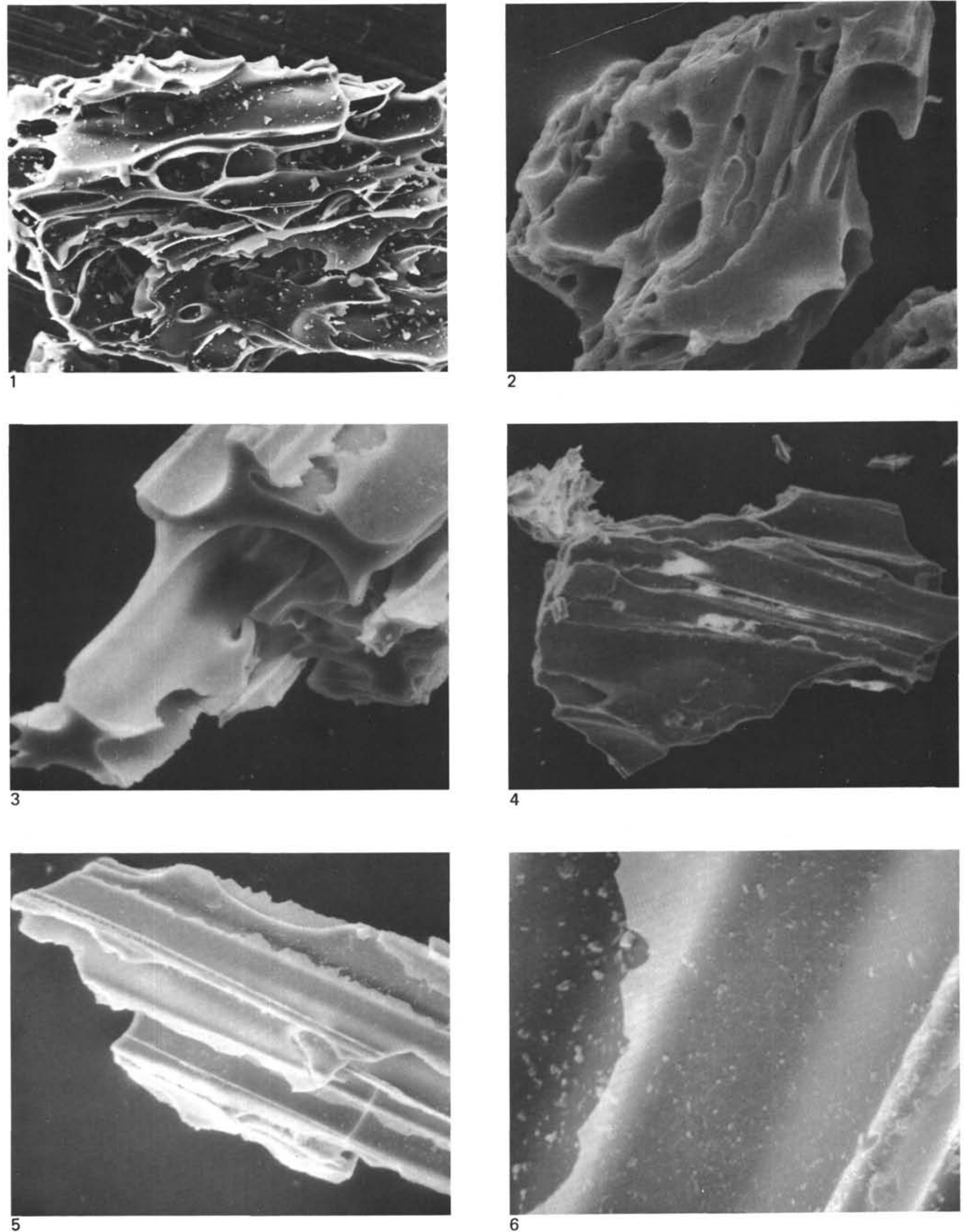
PLATE 3

Progressive Etching of Glass Surface with Age (scanning electron photomicrographs)

Figure 1 Glass shard with low vesicularity and some conchoidal fractures surfaces $(\times 300)$, lower Pliocene, Sample 438A-14-4, $43 \mathrm{~cm}$.

Figure 2 High magnification $(\times 3000)$ of Figure 1 showing almond-shaped etch pits $\left(\mathrm{SiO}_{2}\right.$ content about 73 per cent).

Figure 3 Platy glass shard $(\times 400)$, middle Miocene, Sample 438B-4-1, $77 \mathrm{~cm}$.

Figure 4 Detail of the surface $(\times 3000)$ of Figure 3 showing deeper etching $\left(\mathrm{SiO}_{2}\right.$ content about 75 per cent).

Figure 5 Bubble glass shard included in claystone with diatoms fragments $(\times 800)$, lower Miocene, Sample $439-8-2,124 \mathrm{~cm}$.

Figure 6 Detail $(\times 3000)$ of Figure 5 showing more advanced stage of etching $\left(\mathrm{SiO}_{2}\right.$ content about 69 per cent). 


\section{PLATE 3}
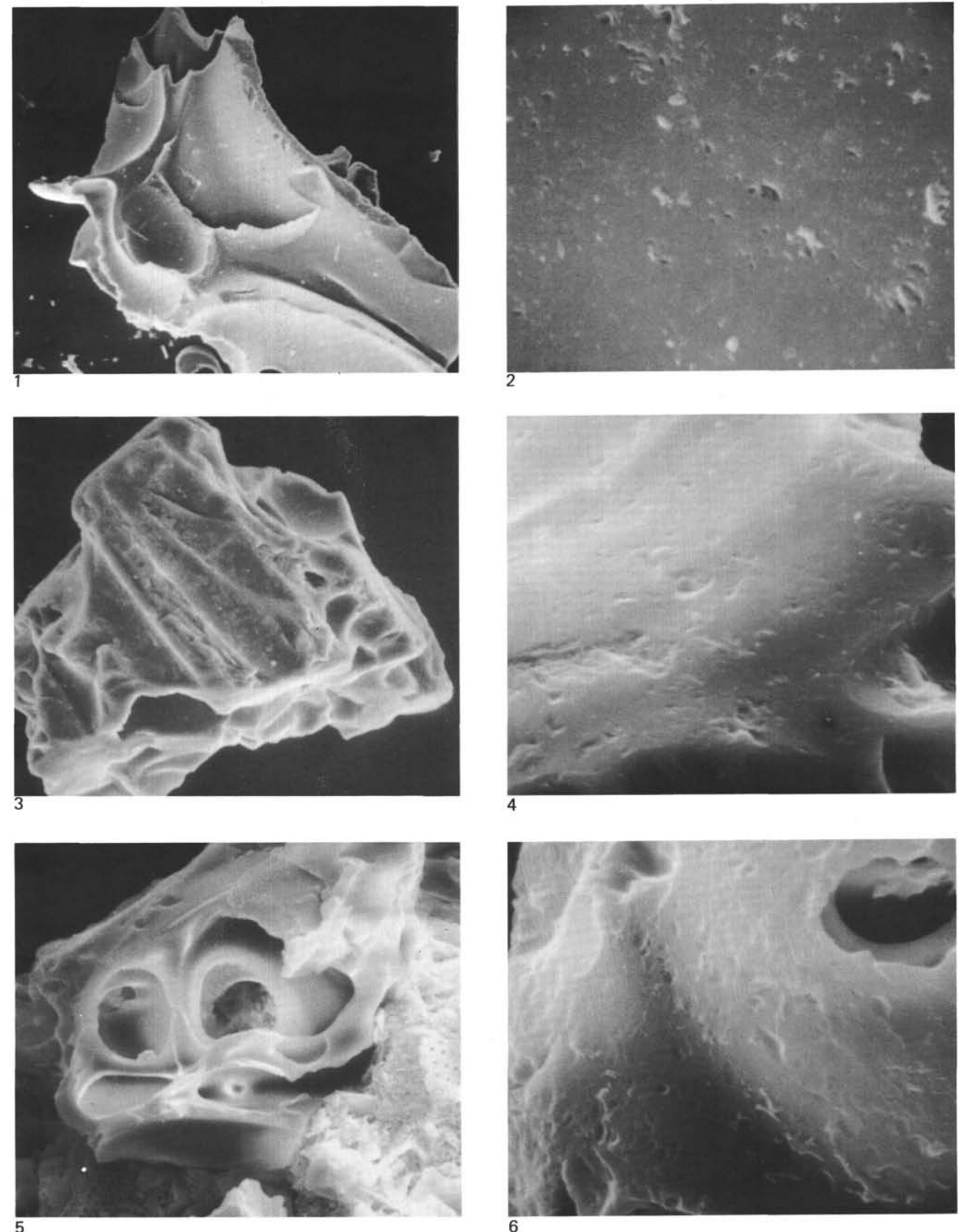